\title{
DETERMINATION OF NEEDS OF BLACK AGED PERSONS IN PORT ELIZABETH: DIRECTION FOR FUTURE INTERVENTIONS
}

\author{
M.M.S. Ntshona
}

\begin{abstract}
Sacial, econommic and health care needs of elderly black persons in Port Elizabeth and areas in its immediate vicinity are imvestigated. Conclusions are drawn from a sample study of 301 elderly people. The investigation reveals that the majority of pensioners are women, their educational standard is below standard 10, and they have litlle vocational or specialized training. A high proportion (86\%) of them are breadwinners and there fore they are unwilling to reside in institutions. Recreational facilities are inadequate. Pension payout points are overcrow ded and disorganized. Also health care services are inaccessible to most elderly people. In view of these findings, a community-based approach to care for the elderly is recommended. The approach should promote social interaction among elderly through establishment of tuncheon clubs and service centres and well-being of all elderly through ge riatric clinics as well as home care services for the infirm. This entails an intersectorial collaboration, with the elderly being fulty involved and participating. Considering the exponential grow th of the elderly population in South Africa, it is imperative that the government and other organizations should take cognizance of studies of this nature when making future decisions as regards the care of this group.
\end{abstract}

\section{OPSOMMING}

Die sosiale, ekonomiese en gesondheidsbehoefles van bejaarde swart persone in Port Elizabeth en die omliggende gebiede word ondersoek. Gewolgtrekkings ward gemaak na aanleiding van 'n proefstudie van 301 bejaardes. Uit die ondersoek bhyk dit dat die meerderheid van pensioenarisse urowlik is, dat hul opvoedkundige viak onder standerd 10 is en dat hulle weinig beroeps-of gespesialiseerde opleiding het. ' $n$ Hoe persentasie (86\%) van hulle is broodwinners en hulle is dus onwillig om in inrigtings te woon. Ontspanningsgeriewe is ie onvoldoende. Pensioenuitbetalingspunte is coroonol en gedesorganiseerd.Gesondheidsdienste is ook onbereikbaar vir die meeste bejaarades.In die lig van hierdie bevindings word 'n gemeenskapsgebaseerde benadering tot die sorg van bejaardes voorgestel. Hierdie be madering behoort sosiale interaksie tussen die aktiewe bejaardes te bevorder deur die stigting van eetklubs en dienssentrums asook die welsyn van bejaardes deur geriatriese klinieke en tuissorgdienste vir swak bejaardes.Dit behels in intersektoriale samewerking wat die volle betrokkenheid en deelname van bejaardes insluit.Wanneer die eksponensiale groei van die bejaardes bevolking in SA in aanmerking geneem word, is dit uiters belangrik dal die regering en ander organisasies kennis moet neem van hierdie en ander soortgehke studies wanneer toekomstige besluite m.b.t. die sorg vir bejaardes geneem word.

\section{INTRODUCTION}

In 1980, elderly persons (men and women older than 65 and 60 years, respectively) comprised approximately $3.78 \%$ of South Africa's population (Van Rensburg, 1984). It has been projected that by the year 2015, this proportion will increase to over $5 \%$ of which about two thirds will be black (black is defined here in terms of the South African Population Registration Act of 1950 (Act No. 30). A recent report of the Central Statistical Services (1991) indicated that the elderly population (60+ years old) comprise $4.3 \%$ of the total South African population. Of these, $55.4 \%$ are blacks (Table 1). The population is "increasing exponentially with time" (Hofmeyr and Mostert, 1989). Proposed improvements in standard of living and lifestyle, modem medicine and improved health care facilities will further contribute to a higher proportion of elderly people in society
(W.H.O.,1974 \& Holmes, 1983). These factors point to an inevitable situation in the near future that a larger elderly population may become dependent upon a smaller proportion of breadwinners. The problem is compounded by the fact that, in the past, the South African government did not cater for the needs of the black elderly. Black people were regarded as temporary sojoumers for the purpose of employment after which they would retum to the rural areas to retire.

The breakdown of the extended family system as well as the traditional rural lifestyle, due to modernization and nural to urban migration, have compelled most of the elderly to reside permanently in urban areas (Holmes, 1983, Hildebrandt, 1992, Ferreira et al, 1993 \& Wessels, 1984). This has created an extra burden on the government and other organizations with regard to provision of essential services which include housing, sanitation and recreational facilities as well as health care.

For these provisions to be effectively planned and provided, it is necessary to determine the needs of the elderly and ensure that they are involved and are fully participating in existing and future community-based developmental projects. In this way, the elderly population will become part and parcel of the community, rather than a burden. Consequently they will be empowered to be active participants. This approach will dispel the prevalent notion that elderly people are passive and frail (O'Brien \& Gillis, 1993)

This study aims to address the above concerns and was inspired by an exploratory survey conducted in Port Elizabeth in April to May 1988 by the researcher. An interview and a questionnaire involving a small sample of elderly persons indicated social and economic hardships they encountered which resulted in ill health. Subsequently, in July to August 1990 a more comprehensive research project was conducted. Port Elizabeth was again chosen. The town is one of many urban areas in South Africa with a significant proportion of black elderly in its population. The objectives of the study were to:

- determine the social, economic and health care needs of the black aged persons in Port Elizabeth 
TABLE Numbers (1 0008) of persons aged $60+$ in aix age groups, by population group.

\begin{tabular}{|c|c|c|c|c|c|}
\hline $\begin{array}{l}\text { Age Group } \\
\text { (years) }\end{array}$ & 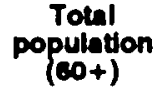 & Balcks & Coloureds & Indlane & Whites \\
\hline$\infty 0-24$ & 683 & 405 & 60 & 23 & 104 \\
\hline $65-60$ & 404 & 274 & 44 & 15 & 160 \\
\hline $70-74$ & 400 & 235 & 31 & 10 & 130 \\
\hline $75-70$ & 211 & 23 & 10 & $\mathbf{5}$ & $\infty$ \\
\hline $80-84$ & 135 & 64 & 11 & 2 & 50 \\
\hline 85t & 85 & 45 & 7 & 1 & 32 \\
\hline TOTAL & 2014 & 1115 & 172 & 57 & 600 \\
\hline
\end{tabular}

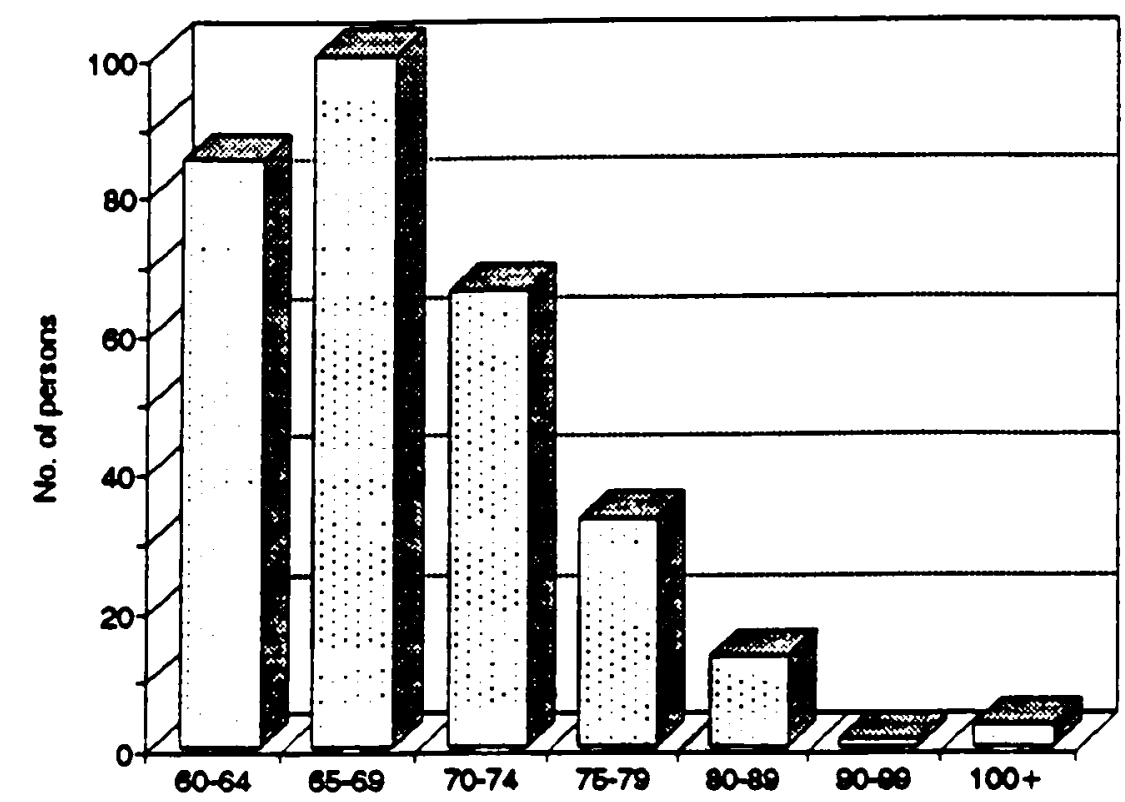

Flgure 1:Age dictribution of black aged persons in Port Elzabeth ( $N=301$ )

- ascertain the necessity for the establishment of service centres, old age homes and frail age homes in Port Elizabeth

- obtain the views of the elderly persons as regards the establishment of these services

- make recommendations for the services of the elderly people to the organizing bodies and the goverument

In 19̀85, the Central Statistics Services for Port Elizabeth reported that elderly people comprised $10.95 \%$ (20656) of a total population of 226080 people over one year old up to an age of 55 years and older. The ratio can be safely assumed to be fairly representauve of all urban areas of the country, although for bigger cities like Johannesburg and Cape Town it could be much higher.

It is realised that the handicaps faced by the elderly in Port Elizabeth revealed by this investigation, are applicable elsewhere in South Africa. Vilakiazi (1994) notes that more than $80 \%$ of the elderly live in impoverished curcumstances, where illiteracy is high and lack of pension and access to health care is prevalent It is noted that in meeting the basic needs, the government proposes that partnership be developed with community- based structures (ANC, 1994) while O'Brien \& Gillis (1993) highlight the need for the government to see the elderly as a major source which could play a significant role in meeting some of the human resource needs of this country. These recommendations could prove invaluable to decision makers in policy formulation and urben planning.

\section{METHODOLOGY}

The study was conducted in ten urben and peri-urban townships of Port Elizabeth.
Random sampling was carried out at pension pay points which included Santa and Empilweni hospitals, New Brighton, Kwazakhele, Zwide and farms (Walmer) Seaview and Greenbushes). Every tenth black elderly person who complied with the criterion of 60 years and above for fenales and 65 years for males was selocted at the pension pay points. Sampling was carried out during the sixteen days the pension was paid out. Twenty (20) subjects were chosen each day. The total was 320 subjocts. Of these, nineteen subjects were lost during interviews due to reasons stated in a subsequent paragraph. The remaining 301 constituted the sample. Five trained home nursing auxiliaries assistod the researcher to collect the data. The questionnaires were delivered to those elderly people who could write and read English, and were collected after completion. The interview schodule was used to collect data from the elderly people who could neither read nor write English.

The study had limitations in that there were no separate registers for pensioners. It was difficult at times to determine exact ages. It was also problematic to distinguish, among the total percentage of the aged population receiving pension, those who were bedridden, or disabled and those receiving pension through the bank. In addition, the survey was carried out just after the period of severe unrest in Port Elizabeth. At that time, house numbers were erased and the elderly people were unsympathetic and unco-operative to anybody coming "from the regime" to ask them questions. Consequently, some elderly people were unwilling to give responses on some aspocts with which they felt uncomfortable. Nonetheless, 301 of them responded.

\section{RESULTS}

\section{Marital Status, Ser and Age \\ Distribution}

Of respondents $48.1 \%$ were married, $40.7 \%$ widowed and the remainder (7.1\%) single, divorced or separated. The survey also indicated that $33.4 \%$ were between the ages of 65 and 69 years, $27 \%$ between 60 and 64 years Three elderly persons were aged 100 years and

\begin{tabular}{|c|c|c|c|c|}
\hline \multicolumn{5}{|c|}{ Table 2Black Aged Uving In Ovorcrowded Housing $(N=301)$} \\
\hline Overcrowding & Frequency & $x_{-}$ & $\begin{array}{l}\text { Cumulatho } \\
\text { Froquency }\end{array}$ & $\begin{array}{l}\text { Cumulattve } \\
\text { Percont }\end{array}$ \\
\hline Yes & 186 & 02.6 & 180 & 22.0 \\
\hline No & 111 & 37.4 & 297 & 100,0 \\
\hline No response & 4 & - & 301 & . \\
\hline
\end{tabular}

\begin{tabular}{|c|c|c|}
\hline \multicolumn{3}{|c|}{$\begin{array}{l}\text { Table 3Reepondente Who Proter to Uwe Independently Within the } \\
\text { Community }(N=301\end{array}$} \\
\hline Independent Living & Frequency & Percent \\
\hline Yes & 243 & $\infty, 0$ \\
\hline No & 27 & 10.0 \\
\hline $\begin{array}{l}\text { No response } \\
\text { Total }\end{array}$ & $\begin{array}{c}31 \\
270\end{array}$ & 1000 \\
\hline
\end{tabular}




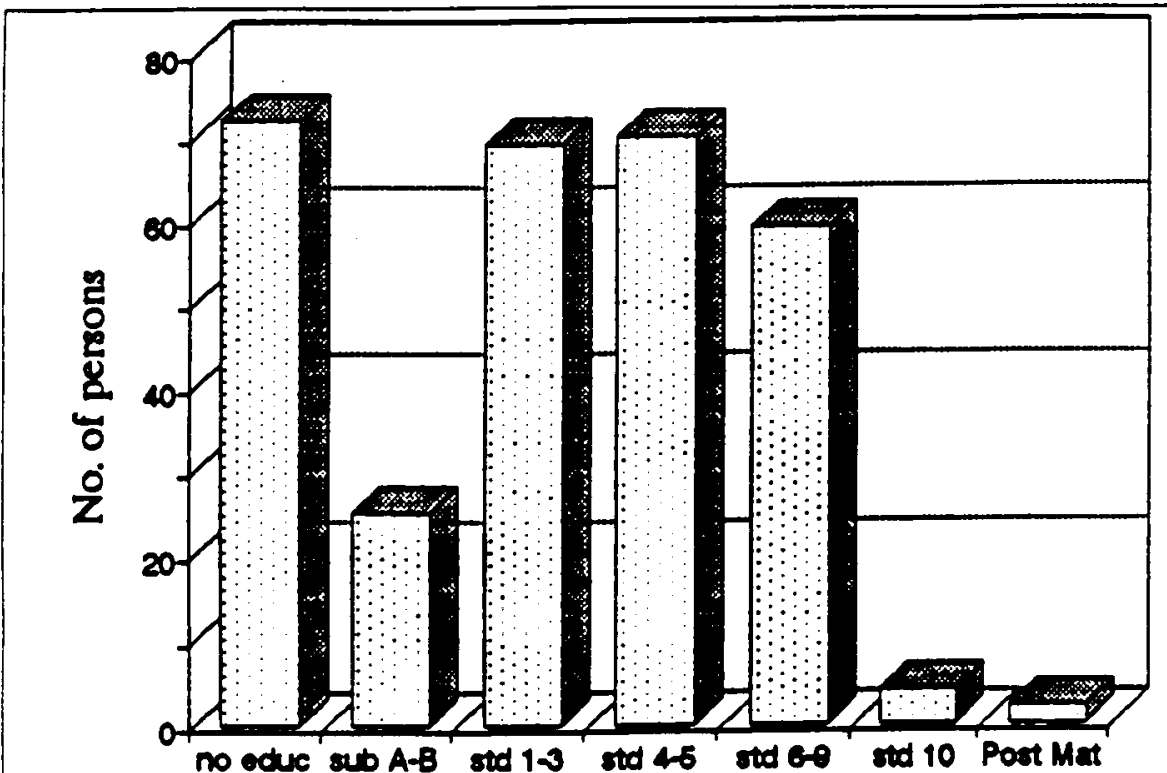

Figure 2:Educatlonal atandards of black aged pereons in Port Elzabeth $(\boldsymbol{N}=301)$

over (Figure 1). In addition to the above, $78.9 \%$ were female, showing a tendency of women to outlive men.

\section{Education and Skills}

Figure 2 highlights the educational standard among the respondents and shows that majority of the sample were poorly educated with only $1.3 \%$ having attained the level of Standand 10. Only $10.4 \%$ of them had received some form of specialist training in their occupation. Thus, their skills they had were centred around work experience.

\section{Housing and Economic Dependency}

The majority $(85.9 \%)$ of the elderly were heads of their households. This is higher than the $75 \%$ observed by Aquilino ( 1990 ), $81.5 \%$ of them resided in houses while the rest lived in shack dwellings and $62.6 \%$ of the sample (Table 2) reported overcrowding. Shack dwellers represented $17.4 \%$ of the sample.

\section{Living Independently within the Community}

Of the respondents $90 \%$ preferred to hve independently but within their communities (Table 3). They identified themselves as an integral part of the communities they lived in and they did not want to be separated from their families. After all, the majority of them were the breadwinners. When asked whether they would like to live in institutions, only 30 responded positively and the rest were against the idea.

\section{Recreational Facilities and Social Activities}

Recreational facilities were generally lacking for all age groups. Social clubs were too few; consequently, only $28.9 \%$ were able to enjoy the services offered by these clubs. Only $27 \%$ were near recreational facilities. The radio was seen as the main form of entertainment by
$73.2 \%$ of the elderly, $24.4 \%$ were able to watch television daily while only $1.4 \%$ frequently went to cinemas. Owing to the low hteracy rate among them, only $11.6 \%$ took some time to read on a fairly regular basis. The church was accessible to most $(67.8 \%)$ elderly people. Hildebrandt (1992) noted the same finding in Duduze township in the PWV Region.

\section{Accessibility of Social Services}

Transportation was satisfactory for $76.4 \%$ of the respondents. The Post Office, however, was rather too far distant according to $77.1 \%$. The banks were even more distant for $86.4 \%$. Just under half (46.5\%) reported they were within easy reach of their pension pay points (Table 4)
Income/Pension Pay-out System

The pension was paid at intervals of two months. The study showed that $93.8 \%$ of the elderly preferred to receive their pension monthly.

\section{Health Care Needs}

The study showed that $44.2 \%$ of the elderly felt that their health was ranging between poor to very poor (Figure 3). Chronic diseases like hypertension, arthritis, heart conditions, diabetes mellitus and lung conditions were common. It is of utmost importance to note the $4 \%$ of the elderly who needed constant help with activities of daily living (Table 5).

Services to cater for the needs of the frail aged should be plannod and established within an accepted and affordable community framework. The elderly voiced a need for home visiting services either by a nurse or a community worker.

\section{DISCUSSION}

The findings of the Port Elizabeth survey, like similar research elsewhere in South Africa, illustrate the obstacles identified by the elderly population in an urben setting which should be addressed by the government through RDP.

The following is a summary of the P.E investigation:

Mast of the elderly persons preferred to stony within the communities in which they belonged. Institutions for the eldenty are not favoured by the majority of the black community who regand the concept as contradictory to tradition.

\begin{tabular}{|c|c|c|}
\hline \multicolumn{3}{|c|}{$\begin{array}{l}\text { Table 4: Acceseibility of social services of the black aged persons } \\
\qquad(N=301)\end{array}$} \\
\hline Social eorvices & $\begin{array}{l}\text { Frequency } \\
\text { within reach }\end{array}$ & Percontage \\
\hline $\begin{array}{l}\text { Supermarket } \\
\text { Church } \\
\text { Transport } \\
\text { Post Office } \\
\text { Bank } \\
\text { Social Cub } \\
\text { Pension pay-point } \\
\text { Recreational tacilities }\end{array}$ & $\begin{array}{c}226 \\
204 \\
230 \\
60 \\
41 \\
87 \\
140 \\
0\end{array}$ & $\begin{array}{l}75.1 \\
87.8 \\
76.4 \\
22.0 \\
13.6 \\
28.9 \\
46.5 \\
3.0\end{array}$ \\
\hline
\end{tabular}




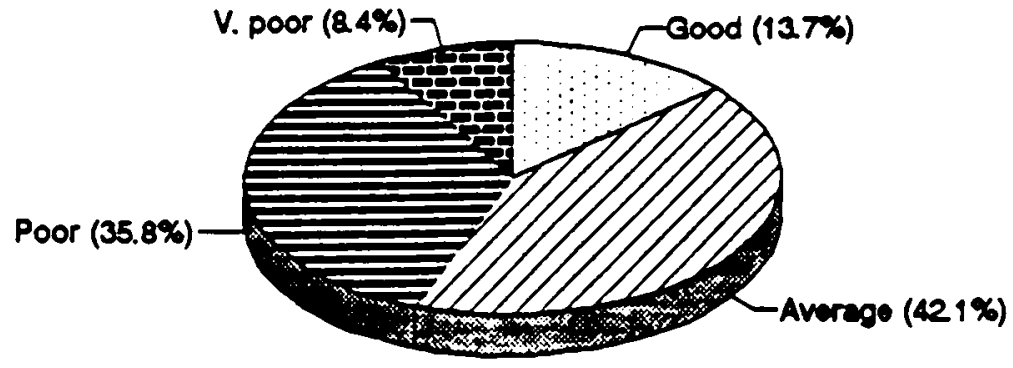

Figure 3: Health status of black aged persons in Port Elzabeth $(\mathrm{N}=301)$

In addition, $90 \%$ of the elderly preferred to live independently within the community (Table 3). They did not want to be separated from their families. Shangase (1991) also emphasized the fact that it is important for the elderly to remain in the community safely, usefully and actively for as long as possible.

Bryrone (1986) and Ferreira et al. (1993) concur with the above findings and recommend that housing policies should aim at assisting and enabling the elderly to find affordable accommodation within the community.

South Africa has a long history of experiencing a severe housing shortage which has affected a vast section of the population, especially blacks (Bell, 1993). In view of the reported overcrowding, accommodation for the elderly should receive prompt attention. Welfare organizations, the business sector and the local authority should work out a co-ordinated strategy to meet this enormous problem (Ntshona 1991, Farreira \& Lamont 1990).

The church meets the spiritual, social and recreational needs of most elderly blacks. It is recommended that service centres and luncheon clubs be established in order to meet some other needs of the elderly people e.g. social interaction with peers, occupational therapy and the enjoyment of a balanced meal in congenial surroundings.

It is noted that the government has met the proposed recommendation of providing income to black seniors on the same criteria as other population groups and pensions are now paid out monthly. What still remains difficult is the congestion and disorganization at pension pay points. Repeated efforts by the South African Council for the Aged (SACA) to have a humane system implemented have resulted in a commission of enquiry, and it is hoped that the situation will be rectified soon (Eckley, 1993).

It is recommended that the community should be involved in helping the elderly to raise funds to meet some of their needs. Hildebrendt (1992) proposed self-help projects in which the elderly could participale and Eckley (1993) mentioned that business could could be undertaken from home.

Self-help schemes like the teaching of handwork, gardening, etc., running a busmess from home, involvement in educare and the elderly initiating social clubs with peers are suggested Moller (1990) in her surdy on the role of black seniors in educare discussed the involvement of the elderly in the oducare system, which could meet some financial, social and psychological noeds

Creation of job opportunities for those from all age groups and who are eligible and healthy is encouraged.Small entrepreneurship and educational opportunities based on need could have social, economic and psychological benefits to the individual (Ntshons, 1991).

Community geriatric clinics to help momitor and maintain the health of the elderty are needed as invariably the elderly suffer from chronic conditions $A$ significant percentage of the elderly was frail and there is a need to plan and establish a frail care service, for example a home care service to support the family A frail care institution is only recommended for the frail and destitute elderly or when the family can no longer cope alone. Eales (1980) proposed that district geriatric clinics for preventive care be established in black townships. Hildebrandt (1992) concurs with this suggestion.Knowledge about self-care could empower elderly people to make appropriate choices in their daily lives to maintam their health and to respond to treatment.

A further recommendation is that pre-retirement programmes should be designed and umplemented five to ten years before retiring. Employers should toy to be involved in the preparation for returement of their employees especially the nonprofessional and the poorly educated groups. The preparation ensures that they will not depend on the state pension only and that the necessary psycho-social adjustments are made.

\section{CONCLUSION}

It can be concluded from this investigation that a community based approach to the care of the elderly should form the central pillar around which programmes for this group of people should revolve. However, the govermment has a role in constructing a clear framework for addressing the needs of the elderly.It should be noted that some of the rocommendations made here are being addressed currently by the community, the South African Council for the Aged and the govermment.It is imperative that the remaining needs be addressed.An endeavour to involve the elderly people actively in planning for their care can only serve to enpower them, an investment that can pay dividends on the long term.

As most needs of the elderly are interwoven and interrelated with those of the other age groups, it is recommended that appropriate community organizations or interest groups should address the neods of the other age groups also e.g. creating employment opporamities for the young adults.Problems of the elderly can be compounded by the frustrated aspirations of their children and grandchildren.

\section{ACKNOWLEDGEMENTS}

Sincere thanks are extended to friends and colleagues at the University of Cape Town, mos notably Professor van Niekerk (Dean of Medical Faculty), Dr. M. Ramphele (Deputy Vice Chancellor), Shirley Churms and Amos Makarau for their advice. Una Kyriacos and Brenda Klingenberg kindly assisted with transiations of the abstract.

\section{REFERENCES}

Aquilino, W.S. (1990): The likelihood of parent-adult child co-residence: Effects of family structure and parental characteristics. The Joumal of Marriage and the Famity. 52:405-19.

A.N.C. (1994): Reconstruction and Development Programme Johannesburg: Umanyano Publications

Bell, S.R. (1993): The elderiy of Mowbray: Seeking accommodation security. Discussion paper. Cape Town: Human Science Research Council/UCT

Brytone, D. (1986): Health needs of the elderty. Workshop on care of the elderly in Zimbabwe. Joumal of Social Development m Africa. School of Social Work 
Eales, J. (1980): Urban black aged. A study by the Transvaal Region of the Urban Foundation. Unpublished manuscript.

Eckley, S. (1993): The future of the council within a new government dispensation Newsletter to members and executive committee members, S.A.N.C.A.5:1-5.

Ferreira, M:; Moller, V.; Prinsloo, F.R. \& Gillis, L.S. (1993): Multidimensional survey report. Aged Policy Recommendations. Thambodala, 4 No: 1-2.

Ferreira, M. \& Lamont, T. (1990): Housing provision of the aged. A plan for action. Pretoria: Human Science Research Council.

Hildebrandt, E. (1992): Self care strategies based on identified needs of the aged in Duduza township. PhD. Thesis, Johannesburg, University of Witwatersrand.

Holmes, L.D. (1983): Other cultures, elder years and introduction to cultural gerontology. Minnesota: Burgess Publishing Company.

Hofmeyr, B.E. \& Mostert, W.P. (1987): Demographic ageing of the South African population: past (1945-1985) and expected (1985-2035) trends. Pretoria: Human Sciences Research Council.
Lawton, M.P. (1992): Generational interdependence: Living arrangements and housing programmes. Southern African Joumal of Gerontology, 1 (1) $1-4$.

Molles, V. (1990): A role for black senions in educare: A community assessment. Pretoria: Human Science Research Council.

Ntshona, M.M (1991): A survey to determine the needs of the black aged persons in Port Elizabeth. MA. Cur dissertation, Pretoria, University of South Africa.

O'Brien, A.; Gillis, L. (1993): The perceived needs of elderly residents of Khayelitsha. Unpublished manuscript. Cape Town: HSRC/UCT, Centre of Gerontology.

R.S.A. (1985): Central Statistics Services, Cape Town: Government printers.

R.S.A. (1991): Central Statistics Services, Cape Town: Government printers.

Shangase, P. (1991): How 10 maintain aged care services in a community in transition. Grey Power 2000. S.A.C.A. National Conference. Unpublished manuscript.

Van Rensburg, F.A.J. (1984): The ageing population. Unpublished manuscript Cape Town: South African Council for the Aged
Vilakazi, P. (1994): Can our govermment accept the challenge. Senior News, S.A.N.C. Aged. No. 1, p.4

Wessels, J. (1984):A concept of villages for the aged in black communities. Un published manuscript.Port Elizabeth

W.H.O. (1974):Planning and organization of geriatric services. Geneva:World Health Organization

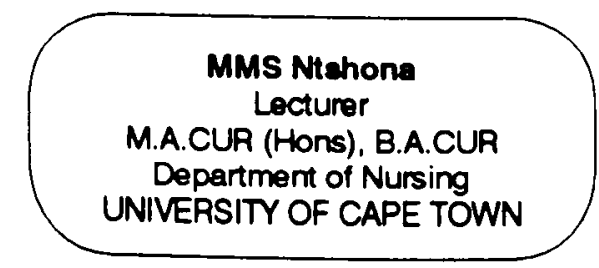

